\title{
Identification of a female sex pheromone in Carcinus maenas
}

\author{
J. D. Hardege $\mathrm{e}^{1, *}$, H. D. Bartels-Hardege ${ }^{1}$, N. Fletcher ${ }^{1}$, J. A. Terschak ${ }^{1}$, M. Harley ${ }^{1}$, \\ M. A. Smith ${ }^{1}$, L. Davidson ${ }^{1}$, D. Hayden ${ }^{2}$, C. T. Müller ${ }^{2}$, M. Lorch ${ }^{3}$, K. Welham ${ }^{3}$, \\ T. Walther ${ }^{4}$, R. Bublitz ${ }^{5}$ \\ ${ }^{1}$ Department of Biological Sciences, University of Hull, Cottingham Road, Hull HU6 7RX, UK \\ ${ }^{2}$ School of Biosciences, Cardiff University, Museum Avenue, Cardiff CF10 3US, UK \\ ${ }^{3}$ Department of Chemistry, University of Hull, Cottingham Road, Hull HU6 7RX, UK \\ ${ }^{4}$ Hull York Medical School, University of Hull, Cottingham Road, Hull HU6 7RX, UK \\ ${ }^{5}$ Center for Environmental and Marine Research, Scarborough Campus, University of Hull, Filey Road, \\ Scarborough YO11 3AZ, UK
}

\begin{abstract}
Despite major progress in our understanding of animal signaling systems, the identification of chemical signals in aquatic organisms is still in its infancy. Exemplary for this is the lack of structural knowledge of crustacean sex pheromones despite their initial description in crabs almost $40 \mathrm{yr}$ ago. We hypothesized that species in which the reproductive event is linked to a short window of mating opportunities centered around the time of ecdysis would be ideal to purify and identify such a cue. Here we present the first identification of a crustacean sex pheromone, the female signal produced by the green crab Carcinus maenas from both conditioned seawater and female urine. We used a bioassay-driven purification scheme combined with a candidate approach focusing on excreted compounds that changed through the course of the female molt cycle. Uridine diphosphate (UDP), a nucleotide accumulated from UDP- $N$-acetylglucosamine during chitin biosynthesis, is the major component of the female crab pheromone and induced all key characteristics of male sexual behavior in bioassays (i.e. pre- and post-copulatory guarding of the female and initiation of mating) at a threshold of $10^{-5} \mathrm{M}$ UDP in seawater. The identification of a nucleotide pheromone in crustaceans will enable future studies on signal specificity, biological function, biosynthesis, reception, and evolution as well as focus its potential use in pest control and aquaculture, thus allowing for a major expansion of crustacean chemical and behavioral ecology research that was hindered by the lack of structural knowledge.
\end{abstract}

KEY WORDS: Crustacean sex pheromone $\cdot$ Identification $\cdot$ Nucleotide $\cdot$ Mate guarding $\cdot$ Carcinus maenas

Resale or republication not permitted without written consent of the publisher

\section{INTRODUCTION}

Although Ryan (1966) demonstrated in an elegant series of experiments conducted more than $40 \mathrm{yr}$ ago that female sex pheromones influence reproductive behavior in malacostracan crabs, the chemical nature of these cues remains unknown (Hardege et al. 2002). This has been attributed to 2 problems: the biological assays are not able to effectively discriminate between signals derived from the opposite sex and other cues such as food (Dunham 1978, 1988), and the analytical methods to purify pheromones from an aqueous environment are challenging (Hardege et al. 2002, Hayden et al. 2007). Many studies have described the existence of aquatic chemical cues as mechanisms that control animal behavior, but few aquatic sex pheromones have actually been identified. Exceptions include the polychaete pheromones and the steroid and bile acid sex pheromones in fish (Dulka et al. 1987, Li et al. 2002, Hardege et al. 2004, Sorensen et al. 2005). Perhaps one of the best-studied crustacean systems for examining sex pheromones is that of the European 
green crab Carcinus maenas (Eales 1973, Seifert 1982, Bamber \& Naylor 1996, Ekerholm \& Hallberg 2005). This species, also known as the shore crab, has recently been introduced to Australia, the USA, and South America (Grosholz \& Ruiz 1995), resulting in ecological and economic damage to native ecosystems and local aquaculture industries.

Green crab mating is confined to the period immediately following the molt (ecdysis) when the female reproductive organs are accessible (Bamber \& Naylor 1996). Pre-copula males are able to sense and select pre-molt females in anticipation of their prime reproductive stage. When a male senses such a female, he rises up on tiptoe, approaches and grasps the female, and manipulates her beneath his abdomen, thus guarding the female in a cradling position (Berrill \& Arsenault 1982). Guarding behavior continues through the molt until the female's carapace has hardened enough to provide protection and to discourage competitive mating, although guarding does not necessarily result in single paternity, as takeovers have been well documented in other crustaceans (for review see Jormalainen 1998). The same pre-copula males are not attracted to inter-molt females, and exposure to other males or inter-molt females evokes fighting behavior (Hardege et al. 2002). This well characterized behavior is easily recognized, being very different from feeding responses (Hayden et al. 2007). It forms the basis of the unambiguous, fast behavioral assay (Hardege et al. 2002) used in this study to aid in the purification and identification of the female-derived sex pheromone.

Since reproduction is linked to the molt, early reports indicated that the molting hormone 20-hydroxyecdysone (20HE) also functions as a female-produced sex pheromone (Kittredge et al. 1971). Recent studies (Hardege et al. 2002) have demonstrated that for many crustaceans, including Carcinus maenas, this is not the case (Hayden et al. 2007). Instead, 20HE plays a role during mating as a sex-specific feeding suppressant for male crabs, thereby reducing the risk of cannibalism of soft-bodied, reproductive females (Hayden et al. 2007).

The aim of this study was to identify the chemical composition of the female sex pheromone in Carcinus maenas using a bioassay-guided purification and analysis scheme coupled with high-performance liquid chromatography (HPLC) separation methods (Hardege et al. 2002) to isolate bioactive compounds from both urine and 'conditioned seawater,' each known to contain the female cue (Hayden et al. 2007).

\section{MATERIALS AND METHODS}

Experimental animals. Carcinus maenas were collected between June and September 2000 to 2007 from the intertidal shore both as individuals and in pre-copula pairs near Forder, Cornwall, UK. Single crabs of both sexes were kept in communal holding tanks $(76 \times$ $64 \times 25 \mathrm{~cm}$ ) supplied with circulating seawater (salinity 32 to $34 \%$ ), while pre-copula pairs were allowed to remain paired and kept in their own holding tanks $(30 \times 20 \times 20 \mathrm{~cm})$ each filtered with a Mini-Aqua-Flow Filter pump. Tanks were checked daily for pre-copula pairs and molting females. All tanks were maintained at $16 \pm 2{ }^{\circ} \mathrm{C}$ and on a $12: 12 \mathrm{~h}$ light:dark cycle. Animals were fed 3 times a week with frozen mussels Mytilus edulis.

Pheromone purification and analysis. Urine was collected daily from paired females $5 \mathrm{~d}$ prior through $15 \mathrm{~d}$ after their molt. Females were strapped to a plastic board with rubber bands, and the third maxillipeds were restrained and fixed. The urine was collected from the opening of the antennal opercula as described by Bamber \& Naylor (1996) using a micropipette attached to an Eppendorf vial. The urine from each individual crab was filtered through a sterile filter (Spin-12000 RPM, centrifuge tube filters, Costar) and frozen at $-20^{\circ} \mathrm{C}$. The females were returned to their individual tanks with the original male partner. Female-conditioned seawater samples were obtained as described by Hardege et al. (2002) by placing a defined number of either pre-molt, post-molt, or intermolt females in freshly sterilized seawater (i.e. 20 females in $250 \mathrm{ml}$ UV irradiated, $0.45 \mu \mathrm{m}$ filtered seawater) for 1 to $2 \mathrm{~h}$ followed by removal of the crabs, filtration $(0.2 \mu \mathrm{m})$, and storage at $-70^{\circ} \mathrm{C}$ until required. To be able to compare samples of crabs at different stages of the molt cycle, and as such identify peaks specific to sexually active females, we also collected urine samples from 10 individuals each of inter-molt males, inter-molt females, and post-molt males.

A multistep strategy (Fig. 1) was used to concentrate the bioactive compounds from the samples, to remove inorganic salt and purify via HPLC for analysis by mass spectrometry (MS) and nuclear magnetic resonance (NMR) imaging. The urine samples were filtered through 3000 Da filters (Microcon YM-3, Millipore) and the subsequent filtrate passed through a $1000 \mathrm{Da}$ filter (Micon Centrifree Micropartition Devices, Millipore). For the larger-volume, female-conditioned seawater samples, an Amicon stirred cell ultrafiltration membrane system $(10 \mathrm{kDa}, 1 \mathrm{kDa}$, and $0.5 \mathrm{kDa})$ was used. To reduce the overall volume of the femaleconditioned seawater samples $(250 \mathrm{ml})$, the filtrate was lyophilized and subsequently redissolved in $12.5 \mathrm{ml}$ of distilled water. Aliquots of the filtered samples were then transferred to $1.5 \mathrm{ml}$ amber glass HPLC vials for fractionation via HPLC. To reduce the impact of inorganic salt in the concentrated samples upon the HPLC analysis, $1 \mathrm{ml}$ of the active sample (as determined via 


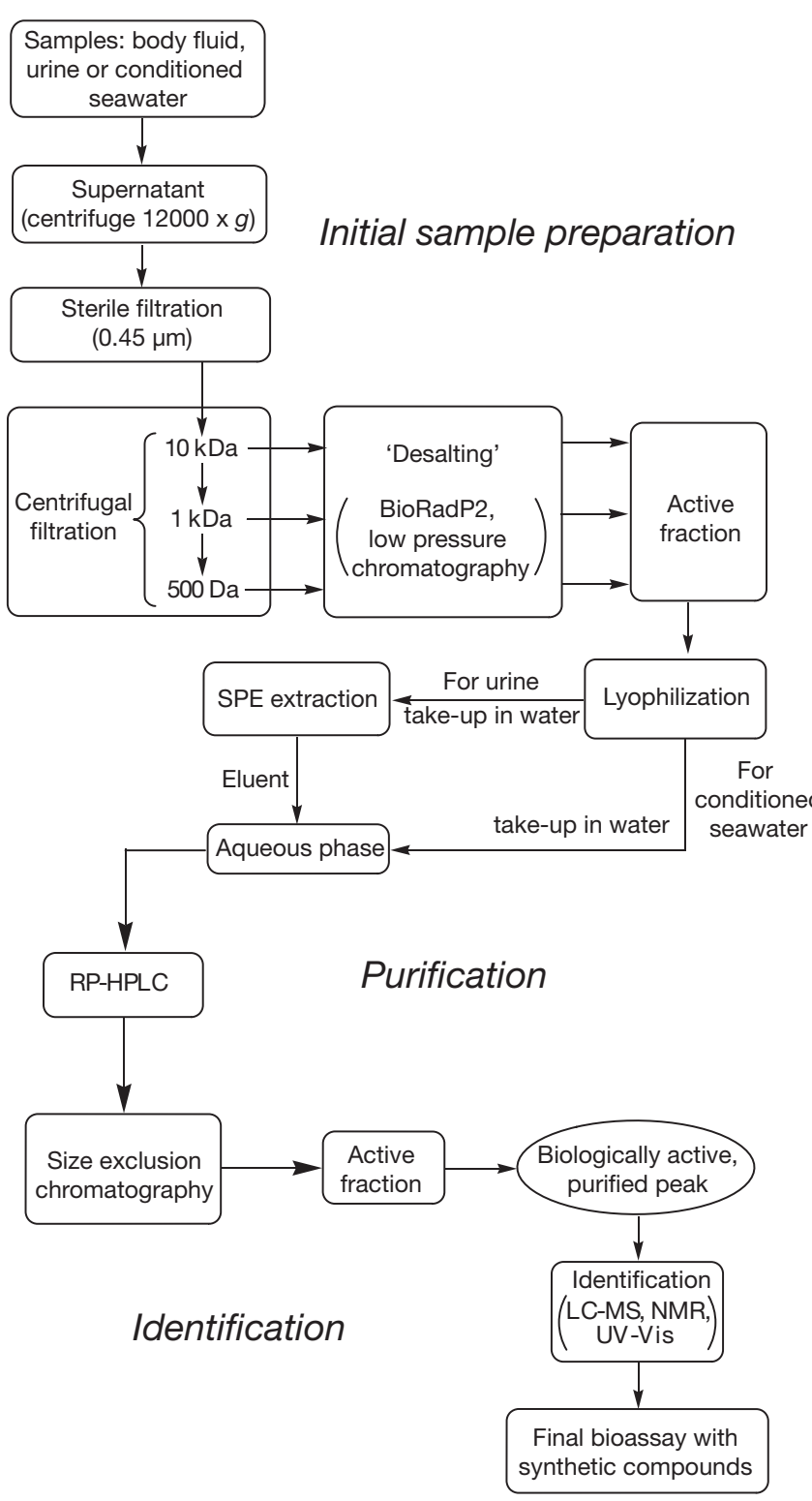

Fig. 1. Carcinus maenas. Purification strategy used to isolate and identify the female-produced sex pheromone. Every arrow represents a step where a bioassay was undertaken to verify the strategy. Assays were against negative control (seawater), positive control (female urine), and sample control (original sample)

the bioassay) was 'desalted' using a BioRad lowpressure chromatography system and a size exclusion gel column (packed with BioRad P2, $50 \mathrm{~cm} \times 1.0 \mathrm{~cm}$, $1.5 \mathrm{ml} \mathrm{min}^{-1}$ flow, UV-detection at $254 \mathrm{~nm}$ ). Fractions were collected at 1 min intervals, bioassayed for sex pheromonal activity and stored at $-70^{\circ} \mathrm{C}$.

Previous attempts to purify the female pheromone (Hardege et al. 2002) showed that the bioactive compound has little to no retention on C18 and SAX solid phase extraction cartridges. Both of these stationary phases were used to remove non-bioactive compounds such as lipids and amines from the urine sample. As described by Hardege et al. (2002), this pre-HPLC preparation included a Bond-Elut ${ }^{\mathrm{TM}}$ C18 cartridge (3 ml, $100 \mathrm{mg}$ sorbent; extraction: condition 3 times $1 \mathrm{ml}$ with ultra-pure water, $1 \mathrm{ml}$ of the sample loaded, and fractionated with $1 \mathrm{ml}$ methanol/water gradients of $10 \%$ increments using a Bond-Elut ${ }^{\mathrm{TM}}$ system, Varian; final elution was with $1 \mathrm{ml}$ methanol:chloroform 1:1). A strong anion-exchange (Bond-Elut ${ }^{\mathrm{TM}} \mathrm{SAX}, 3 \mathrm{ml}$, $100 \mathrm{mg}$ sorbent) cartridge that is ideal for the isolation of weak acids from aqueous solutions was used in the next purification step. The cartridge was pre-conditioned (solvated) using methanol (1 ml) and the SAX chloride counter-ion replaced by a less selective ion. This was undertaken by rinsing the column with deionized water, followed by $1.5 \mathrm{ml} 0.1 \mathrm{M} \mathrm{KH}_{2} \mathrm{PO}_{4}$ buffer, $1 \mathrm{ml}$ sample loaded and then eluted with $2 \mathrm{ml}$ $20 \mathrm{mM}$ phosphate buffer.

The HPLC was an Agilent 1100 system consisting of a quaternary pump, degasser, autosampler (100 $\mathrm{\mu l}$ loop), temperature-controlled column compartment, diode-array detector (scanning between 200 and $300 \mathrm{~nm}$ ), and fraction collector, all interfaced with Agilent ChemStation software (Rev. A.10.01). For the pheromone analysis, 6 different HPLC columns and 20 different solvent gradient systems (not described here) were used to achieve a separation of the bioactive peak originally described by Hardege et al. (2002) as eluting near 2.5 min from a Lichrospher ${ }^{\mathrm{TM}}$ RP18 column $(4.6 \mathrm{~mm} \times 250 \mathrm{~mm}$, mobile phase: water, $1.0 \mathrm{ml} \mathrm{min}^{-1}$ ). In addition to the Lichrospher ${ }^{\mathrm{TM}} \mathrm{RP} 18$ column, other columns used were (1) Phenomenex Synergi Fusion RP column $(4.6 \mathrm{~mm} \times 250 \mathrm{~mm}$; mobile phase: $0.2 \mathrm{M} \mathrm{KH}_{2} \mathrm{PO}_{4}$ buffer $\mathrm{pH}$ 5.5, $1 \mathrm{ml} \mathrm{min}^{-1}$ ); (2) Phenomenex Sphereclone SAX column (4.6 mm $\times$ $250 \mathrm{~mm}$; mobile phase: Buffer A $0.04 \mathrm{M} \mathrm{KH}_{2} \mathrm{PO}_{4}, \mathrm{pH}$ 5.5; Buffer B 0.5 M KH $\mathrm{PO}_{4}, \mathrm{pH} \mathrm{5.5;} 0$ to $100 \% \mathrm{~B}$ in $26 \mathrm{~min}, 1 \mathrm{ml} \mathrm{min}^{-1}$ ); (3) Phenomenex Discovery RP18 column $(4.6 \mathrm{~mm} \times 250 \mathrm{~mm}$; mobile phase: $0.5 \mathrm{M}$ $\mathrm{KH}_{2} \mathrm{PO}_{4}, \mathrm{pH} 6.0,1 \mathrm{ml} \mathrm{min}{ }^{-1}$ ); (4) Shodex OHpak SB802-HQ size exclusion column $(300 \mathrm{~mm} \times 8.0 \mathrm{~mm}$; size range: $<4 \mathrm{kDa}$, mobile phase: $0.5 \mathrm{M} \mathrm{KH}_{2} \mathrm{PO}_{4}, \mathrm{pH} 6.0$,

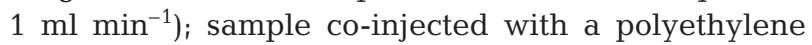
glycol standard (MW 940, 580, 400 mixture; Phenomenex); and (5) Jordi Gel DVB $100 \AA$ size exclusion column (250 mm $\times 10 \mathrm{~mm}, 100-5000 \mathrm{Da}$; mobile phase: water, $\left.1 \mathrm{ml} \mathrm{min}^{-1}\right)$; sample co-injected with a polyethylene glycol standard (MW 940, 580, 400 mixture; Phenomenex).

Fractionation of bioactive peaks was also undertaken using a variety of solvent systems. For example with the Phenomenex Synergi Fusion RP column, different methanol/water and acetonitrile/water gradients were used having various $\mathrm{pH}$ and $\mathrm{KH}_{2} \mathrm{PO}_{4}$ buffer 
strengths, as well as the inclusion of $0.1 \%$ trifluoroacetic acid (TFA). The conditions listed with the HPLC columns above represent those chromatographic systems utilized for the separation of the bioactive peak fractions. The most recently used HPLC method (see Fig. S6a in the Supplement at www.int-res.com/ articles/suppl/m436p177_supp.pdf) made use of a TSK gel ODS-100V $4.6 \mathrm{~mm} \times 250 \mathrm{~mm}, 5 \mu \mathrm{m}$ particle size, HPLC column (TOSOH Biosciences). The mobile phase used was a 2-solvent system with Solvent A (20 mM tbutylamine, $\mathrm{pH}$ 6.8) and Solvent B (A plus 10\% methanol) run at a gradient of 0 to $100 \%$ B over 35 min, hold for $15 \mathrm{~min}$, then post run back to A for $10 \mathrm{~min}$ to give a total run time of $50 \mathrm{~min}$ at a flow rate of $1 \mathrm{ml}$ $\min ^{-1}$ at $25^{\circ} \mathrm{C}$. The HPLC detector was as above, a DAD UV/Vis at $260 \mathrm{~nm}$.

Confirmation of the identity of the pheromone was initially achieved through co-injection of synthetic pheromone uridine diphosphate (UDP, Sigma) with a purified urine sample using the above listed chromatographic methods (see Fig. S6) to purify the pheromone. To verify the nucleotide structure, the synthetic pheromone and the HPLC fraction containing the authentic pheromone isolated from urine were analyzed via direct inlet electrospray MS, and the mass spectral data were compared to a variety of synthetic nucleotides including those that either had uridine or glutamine as the base (UMP, UDP, UTP, GMP, GDP, GTP, CAMP, AMP, ADP, and ATP; Sigma-Aldrich). For this, a Hypersil ODS $5 \mu \mathrm{m}(4.6 \mathrm{~mm} \times 250 \mathrm{~mm})$ column with $50 \%$ methanol in water at $1 \mathrm{ml} \mathrm{min}^{-1}$ was used with synthetic standards of the nucleotides (as above) and 20HE. Liquid chromatography (LC)-MS studies were undertaken at Hemel Hempstedt (ThermoQuest) and Agilent using Finnigan LCQ ion trap and Agilent 6100 Quadrupole mass spectrometers using APCI, $\mathrm{ESI}^{+}$, and ESI ${ }^{-}$modes. At Hull University, we used a Varian 500MS ion trap LC-MS system with a Varian ProStar LC212 binary solvent delivery system and a Varian ProStar 410 autosampler. The instrument was used in positive ion electrospray mode, and data were acquired and processed using the Varian MS Workstation software running on a dedicated PC-based data system. Electrospray (ESI) using nitrogen as the nebulizer gas $\left(70.0 \mathrm{psi}, 60^{\circ} \mathrm{C}\right.$, drying gas at $330^{\circ} \mathrm{C}$, needle voltage $-5 \mathrm{kV}$ ) producing negative ions was used (mean scan rate $4.26 \mathrm{~s} \mathrm{scan}^{-1}$, data acquisition rate $0.23 \mathrm{~Hz}$, multiplier offset $200 \mathrm{~V}$ ). The LC column and solvents were as described for Fig. S6A (in the Supplement), and the solvent flow rate was $1 \mathrm{ml} \mathrm{min}^{-1}$.

For NMR, samples were prepared by dissolving a UDP sodium salt standard or $200 \mathrm{ml}$ of lyophilized crab urine sample in $500 \mathrm{ml}$ of $\mathrm{D}_{2} \mathrm{O}$. All NMR experiments were carried out on a Bruker Avance II $500 \mathrm{MHz}$ spectrometer using a $5 \mathrm{~mm}$ liquid state probe operating at frequencies of $500.1013 \mathrm{MHz}$ for ${ }^{1} \mathrm{H}$ and 202.404 for ${ }^{31} \mathrm{P}$ measurements. ${ }^{1} \mathrm{H}$ experiments were conducted with a $\mathrm{p} / 2$ pulse length of $7 \mathrm{~ms}$, a relaxation delay of $4 \mathrm{~s}$, and $64 \mathrm{kB}$ scans. ${ }^{31} \mathrm{P}$ measurements were performed with a typical p/2 pulse length of $11 \mathrm{~ms}$, a relaxation delay of $2 \mathrm{~s}, 64 \mathrm{k}$ scans with heteronuclear proton decoupling of typically $20 \mathrm{kHz}$ applied during the acquisition time. Measurements were referenced to tetramethylsilane or $85 \%$ phosphoric acid at $0 \mathrm{ppm}$ for ${ }^{1} \mathrm{H}$ and ${ }^{31} \mathrm{P}$ measurements, respectively. All samples were measured at $278 \mathrm{~K}$.

Behavioral assays. To ensure that the bioassay specimens were physiologically in the correct state and able to respond to female cues, only pre-copula males from pairs were used for the behavioral assays. We restricted bioassays to the main reproductive season (June to September) using mainly large, dominant males, as they were more likely to respond to female signals (Sneddon et al. 2003). The assays were adapted from Hardege et al. (2002) and followed the principle that males were exposed to an object not resembling a sexually active female crab with the substances under investigation added to induce a response. The experimental male $(n=40)$ was placed in an observation glass aquarium $(30 \times 20 \times 20 \mathrm{~cm}$, covered on 3 sides to minimize optical interference from the surroundings) with seawater $(32 \%)$ at ambient temperature $\left(16^{\circ} \mathrm{C}\right)$ and allowed to acclimatize for 10 to $20 \mathrm{~min}$. Before each experiment, a yellow natural sponge, smaller ( 2 to $3 \mathrm{~cm}$ diameter) than the test male crab's carapace, was placed in a glass beaker with $200 \mathrm{ml}$ sterile filtered $(0.45 \mu \mathrm{m})$ seawater and $1 \mathrm{ml}$ of the stimulus (fractionated urine samples or $10^{-4} \mathrm{M}$ synthetic pheromone) for $30 \mathrm{~min}$. As a control, the sponge was treated only with seawater. The sponge was placed slowly into the aquarium, and the behavior of the crab was observed for a period of $20 \mathrm{~min}$. As described by Hardege et al. (2002), a positive result required the male to walk above the sponge and attempt to grasp and lift it with its chelipeds and second pair of walking legs, thus demonstrating the typical 'guarding behavior.' This stereotyped reproductive behavior has been described by a number of authors (Hardege et al. 2002, Bublitz et al. 2008, Fletcher \& Hardege 2009) to significantly contrast with the responses to feeding stimuli whereby the crab moves its chelipeds in a type of digging move and never attempts to grasp the object (pseudo female), turn it, and move it into the mating stance (Berrill \& Arsenault 1982, Bamber \& Naylor 1996, Hayden et al. 2007). We also used the scale described by Hardege et al. (2002) to grade male responses to distinguish between relatively unspecific responses such as induction of the tip-toe behavior from full sexual responses such as grasping and attempted copulation. In the data analysis e.g. of the HPLC fractions, only those stereo- 
typed full responses at grades 4 and 5 (see Hardege et al. 2002 for details) were assigned as positive responses. Verification of results was also undertaken by adding a positive control (molted female) to the males used in the bioassays after an experiment, although this was not always possible since the availability of freshly molted females as positive controls was limited. Bioassays were undertaken 'blind,' with the observer of a test not informed as to the exact nature of the sample being tested. To test the bioactivity of synthetic UDP, 3 trials with 20 crabs each were undertaken (see Fig. 5a). In the first trial, individual, randomly selected crabs were tested using exposure to a control sponge and independently towards a UDPtreated sponge. Trials 2 and 3 were slightly different, as tests on UDP/control were undertaken with the same crab, initially tested on a control sponge, the sponge removed, treated with UDP and returned to the crab ( $\mathrm{n}=2$ per trial), therefore producing linked before-after trials. Data analysis made use of a MannWhitney test for trials 1 and 2 and separate Wilcoxon matched pair tests for trials 2 and 3 .

Both negative (filtered sea water) and positive (female-conditioned water) controls were used when testing whole samples and fractions collected during the signal purification steps shown in Fig. 1. As described by Hardege et al. (2002), we calculated the total bioactivity of a sample in bioassay equivalents (BE), thus representing the number of positive responses (in males) that could potentially be elicited with a sample. This allowed us to evaluate at any step of the purification procedures to identify where losses in bioactivity of a sample/peak occurred by comparing its activity to the starting sample (i.e. urine). For the statistical analysis, chi-squared was employed using Fisher's exact test to compare the pheromone to the control experiments.

Choice chamber assays. To examine whether the female pheromone can also serve as an attractant over distance for males and cause them to move towards a female or its odor, a choice chamber flume was used (Fig. 2); the tank measured $2 \times 0.5 \mathrm{~m}$ and had a depth of $29 \mathrm{~cm}$. A flow velocity of $40 \mathrm{~cm} \mathrm{~min}{ }^{-1}$ was used. Addition of the chemical stimulus was controlled via a Masterflex L/S peristaltic pump at a rate of $0.5 \mathrm{ml} \mathrm{min}^{-1}$. Glycine (a known attractant associated with feeding employed here as a positive control, see Hayden et al. 2007) and UDP at $10^{-4} \mathrm{M}$ were used for this purpose. Individual male crabs ( $\mathrm{n}=$ 20) were placed in a holding chamber within the flume and left to acclimatize for at least $1 \mathrm{~h}$. Once the divider to the main flume was released, the behavior was observed and recorded for future reference by video for the experimental period of $15 \mathrm{~min}$. Data were analyzed using SPSS v.13.0. The data were also checked initially for normality and remained non-normally distributed after arcsine square root transformation. A Wilcoxon signed-ranks test was used to compare preferences for the pheromone over glycine.

\section{RESULTS}

In the current study we used a multi-step purification procedure (see Fig. 1) that is based on an earlier study (Hardege et al. 2002) to desalt the samples, remove organic material that showed no bioactivity, and fractionate the samples in order to purify the bioactive compound(s) from 2 sources, urine and crab-condi-
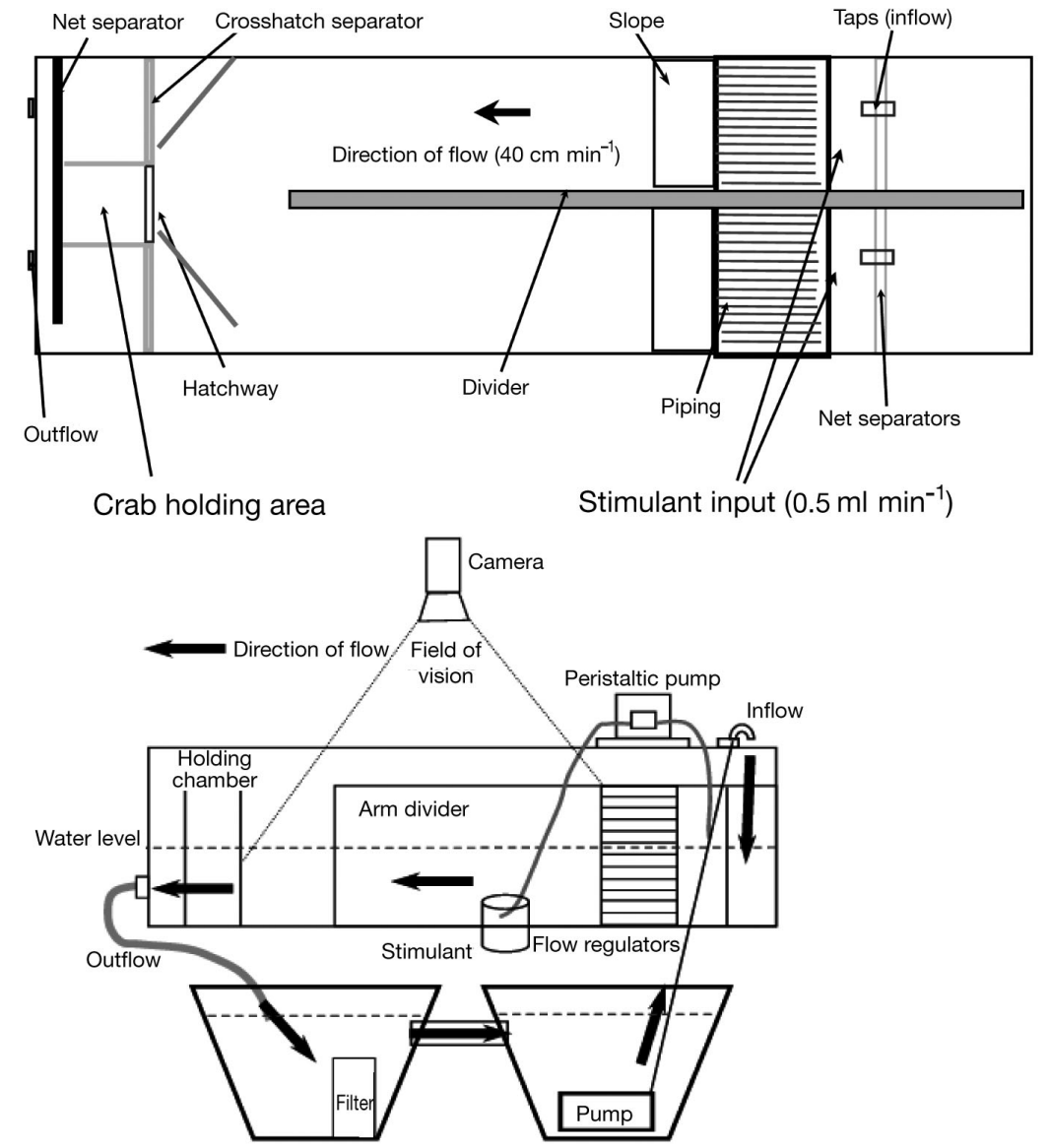

Fig. 2. Choice chamber olfactometer used in the bioassays; the tank measured $2 \times 0.5 \mathrm{~m}$ and had a depth of $29 \mathrm{~cm}$. A flow velocity of $40 \mathrm{~cm} \mathrm{~min}^{-1}$ was used; the double tank reservoir allowed for 20 min of experimental observation before any recirculating seawater appeared in the system again 
tioned water. At every step of the purification strategy that was developed over 5 summer breeding seasons, the extracts and fractions were tested against 2 negative controls (blank seawater control treated identical to the urine sample, and a urine sample from immature males) and a positive control (female urine). The primary challenge in the elucidation of the pheromone was that the cue co-eluted with the inorganic salts found in both body fluids (here urine) and seawater. A BioRad P2 packed column with a low-pressure chromatographic system used in our previous study (Hardege et al. 2002) was useful in desalting the samples. Nevertheless, the pheromone was not completely resolved, producing some overlap with the tail-end of the inorganic salt band. Through the trials of a variety of elution conditions using 5 different HPLC columns and procedures (see 'Materials and methods' for details), the best separation of the pheromone from the reduced inorganic salt contamination was obtained using a Phenomenex Synergi Fusion RP column $(4.6 \mathrm{~mm}$ $\times 250 \mathrm{~mm}$, fitted with a Phenomenex C18 guard column i mobile phase: $0.2 \mathrm{M} \mathrm{KH}_{2} \mathrm{PO}_{4}, \mathrm{pH} \mathrm{5.5,1} \mathrm{ml} \mathrm{min}^{-1}$ at $28^{\circ} \mathrm{C}$; injection volume: $100 \mu l_{i}$ detection: scanning 200-300 nm). Previously, Hardege et al. (2002) found that a significant proportion of the bioactivity of the samples was confined to the fraction representing the retained residue of the $0.5 \mathrm{kDa}$ membranes. Washing the filter residue with ultraclean $18 \mathrm{M} \Omega, 0.2 \mu \mathrm{m}$ filtered water resulted in a dramatic reduction of residual inorganic salt in the bioactive sample. Fig. 3 shows the HPLC analysis of female-conditioned seawater with the bioactive peak eluting near $3.3 \mathrm{~min}$. None of the other peaks seen in the urine extract chromatogram showed any bioactivity on males, nor did any combinations of fractions that did not contain the large peak at 3.3 min (data not presented, as all were 0) and none of the peaks in urine samples seen in Fig. 4 other than that at 3.3 min was detectable in female-conditioned seawater samples analyzed.

To reduce the number of potential bioactive compounds in the complex matrix of urine, the purification scheme also made use of a metabolomic type approach, namely those metabolites stemming from the physiological changes occurring during the female molt. The HPLC chromatograms of samples from intermolt females (data not shown) and males were compared to samples from pre- and post-molt females, all of which with the exemption of pre- and post-molt female urine showed no bioactivity upon sexually active males (see Hardege et al. 2002). When following the multistep purification procedure shown in Fig. 1 and injecting the resulting extract, we found that the only significant difference between these samples and those from sexually active, pre- or post-molt females was the occurrence of a peak at 3.3 min shown in
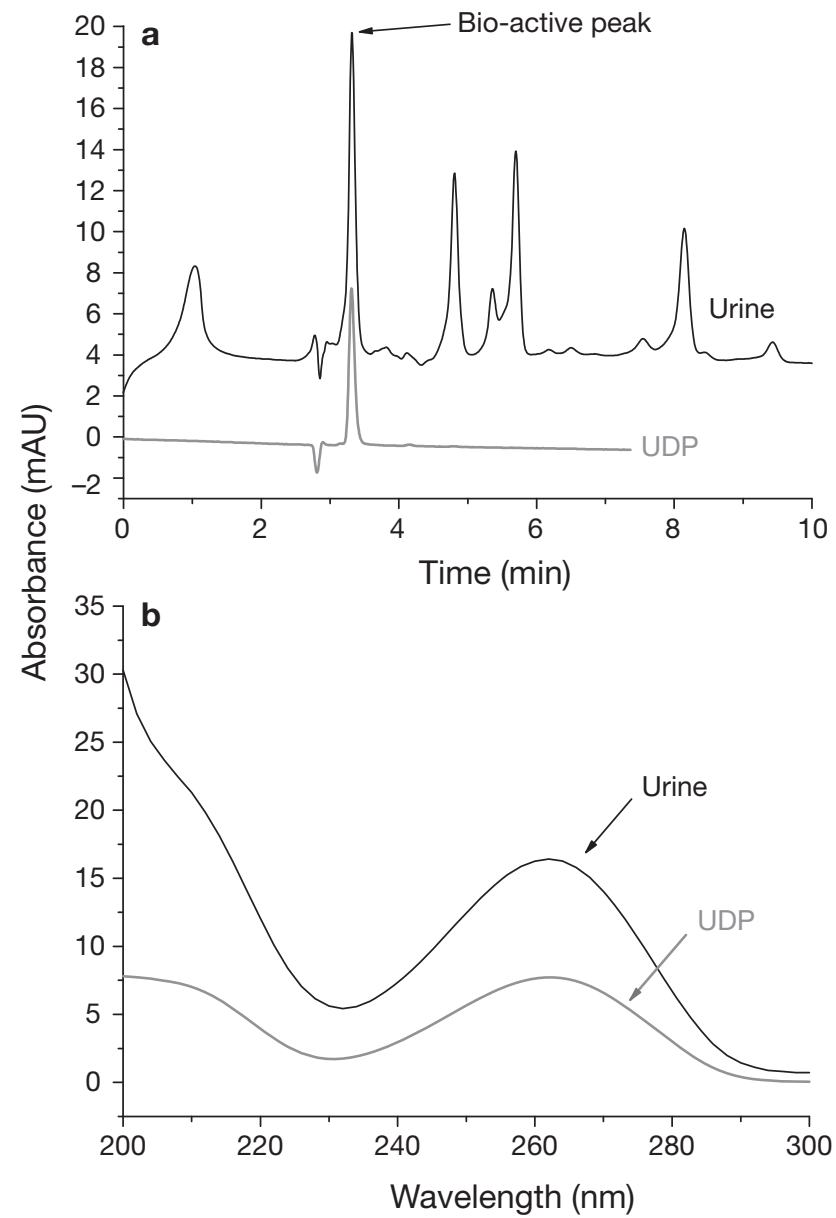

C

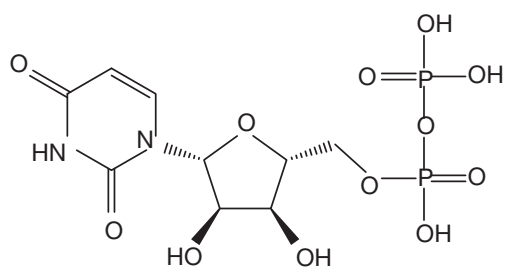

Fig. 3. Carcinus maenas. (a) Comparison of pheromone-containing female urine sample and synthetic UDP. The chromatogram shows the HPLC analysis of $10 \mu$ l of female urine ( 2 d post-molt, black line) and synthetic pheromone, UDP (grey line). HPLC conditions used were: Phenomenex Synergi RP Fusion column $(4.6 \mathrm{~mm} \times 250 \mathrm{~mm})$; mobile phase: $0.2 \mathrm{M}$ $\mathrm{KH}_{2} \mathrm{PO}_{4}$ buffer, $\mathrm{pH} 5.5 ; 1 \mathrm{ml} \mathrm{min}{ }^{-1}$. The chromatogram of female urine shows the bioactive peak appearing at $3.3 \mathrm{~min}$. Note the unresolved shoulder peak; taken together, this represents both tautomeric forms of UDP. (b) UV spectrum of female urine and UDP (maximum absorbance at $260 \mathrm{~nm}$ ). (c) Structure of synthetic pheromone (UDP), which was $100 \mu \mathrm{l}$ at a concentration of $10^{-5} \mathrm{M}$. mAU: milli-absorbance units

Fig. 3. This confirms our earlier hypothesis that this peak represents the female molt-related chemical signal (Hardege et al. 2002).

The cue did not dissolve in the organic solvents tested as described earlier (Hardege et al. 2002), and it 

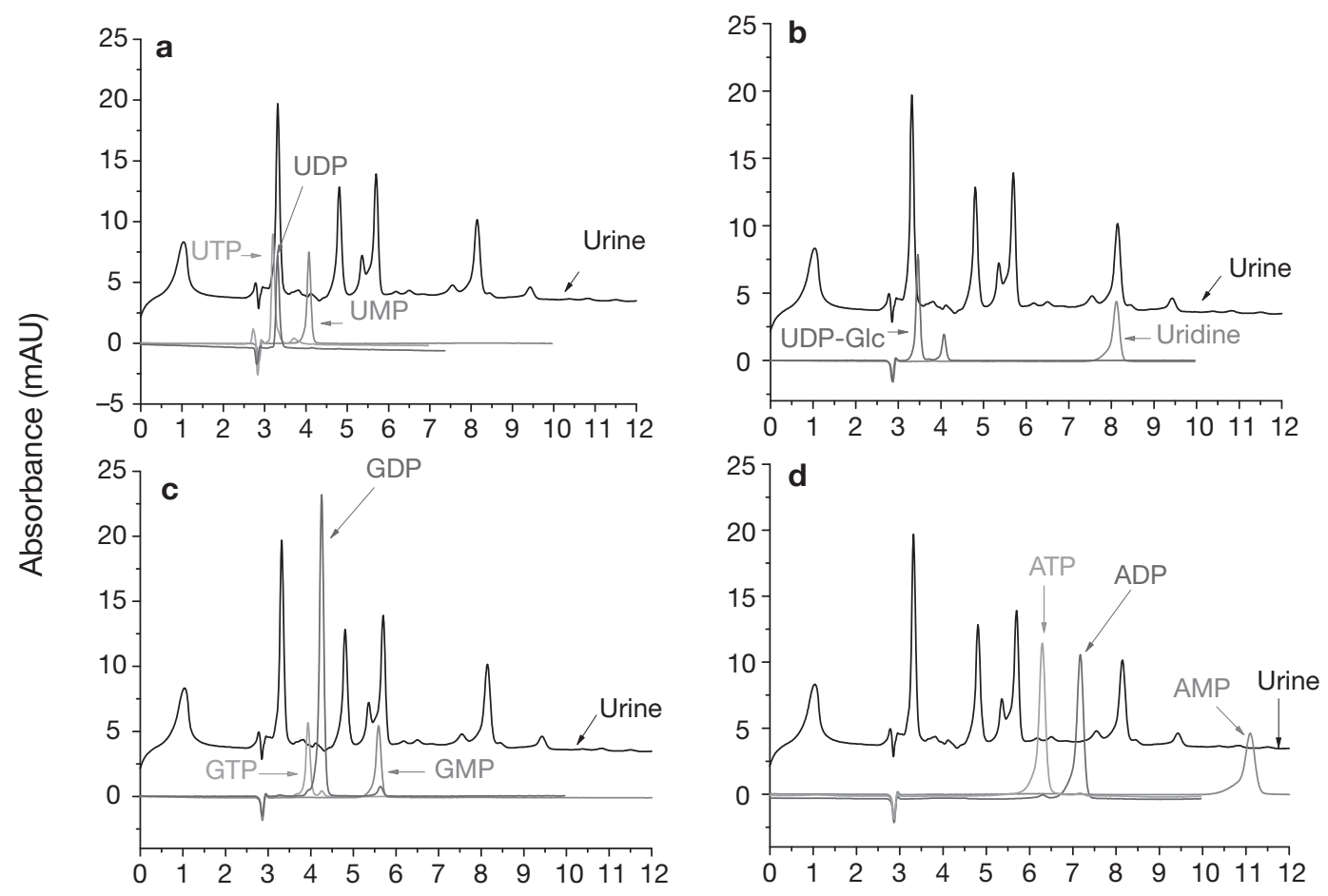

Time (min)

Fig. 4. Carcinus maenas. Chromatograms of HPLC analysis of synthetic nucleotide standards compared to $100 \mu$ female urine (2 d pre-molt). Analysis used a Phenomenex RP Fusion column with $0.2 \mathrm{M} \mathrm{KH}_{2} \mathrm{PO}_{4}$ buffer (pH 5.5) at $1 \mathrm{ml} \mathrm{min}^{-1}$ flow rate. Overlaid chromatograms of HPLC analysis with $20 \mu$ nucleotide standards $\left(5 \times 10^{-5} \mathrm{M}\right)$ : (a) UMP, UTP, (b) uridine, UDP-glucose, (c) GMP, GDP, GTP, (d) AMP, ADP, and ATP

was not retained on C18 SPE cartridges, but did have very weak retention on anion exchange substrates. The substance displayed UV absorbance at $264 \mathrm{~nm}$, contrary to our initial predictions (no UV maximum between 200 and $300 \mathrm{~nm}$; Hardege et al. 2002). Taken together, the analytical data and physicochemical characteristics of the pheromone suggested with high probability that the compound was a nucleotide or nucleoside. The bioactive fractions from both the urine samples and the conditioned seawater samples were injected onto the HPLC, and the resulting chromatographic data (retention index, UV spectra) were compared to a variety of synthetic nucleotides that were co-injected (Fig. 4). For this, 3 different HPLC separation systems were used: a Phenomenex Synergi Fusion RP column, a Phenomenex Sphereclone SAX column, and a Phenomenex Discovery RP18 size exclusion column as means to separate the compounds. The fractionated bioactive pheromone peak was further confirmed as UDP through co-injection of the samples with synthetic UDP, overlaying of HPLC traces (see Fig. S6), as well as repeating the entire purification procedure (Fig. 1) using $10^{-4} \mathrm{M}$ UDP added to intermolt male urine (which does not contain significant levels of UDP), thus also providing us with an internal positive standard usable to evaluate the efficiency of the purification procedures. This allowed for comparison of e.g. the spectroscopic data using a realistic matrix (urine) rather than distilled water. Figs. $3 \& 4$ show that the retention time and the UV absorbance of synthetic UDP are identical to that of the biologically active peak in female urine. Fig. S6a (in the Supplement) shows the co-injection of synthetic UDP to the bioactive fraction obtained from female urine with only the UDP peak increasing, as such confirming its chemical identity as UDP. Interestingly, in all chromatograms, the UDP peak showed shoulder peaks. When samples were analyzed using the Phenomenex Synergi Fusion RP column with $0.1 \%$ TFA added, the pheromone peak changed into a double peak. Simpkin (1978) describes how nucleotide bases, particularly uracil, are liable to undergo tautomeric transformations in aqueous media. Of all the nucleotide bases, only adenine in aqueous solutions has predominantly an aromatic structure; this is associated with the relatively low solvation energy in this case. In accordance with this, our chromatograms of female samples showed no evidence for peaks or UV spectra of UMP, UDP-Glucose, GMP, GDP, GTP, cAMP, AMP, ADP, and ATP, but showed an unresolved shoulder peak for UDP 
(Fig. 4) potentially representing traces of UTP. The final confirmation of the bioactive peak to be UDP via LC-MS (Figs. S1 \& S2 in the Supplement) and NMR (Figs. S3 to S5 in the Supplement) proved complex, as it was difficult to ionize using the positive $\left(\mathrm{ESI}^{+}\right)$mode in electrospray MS, and as such the measurements provided no useful spectra for its identification. Using negative ion electrospray MS, it is possible to detect UDP in the bioactive fraction in the urine samples, although the detection limit threshold for this is very high at $10^{-3} \mathrm{M}$. Thus the MS spectra supplied in the Supplement can only be used to confirm that UDP is actually present in the bioactive peak by comparing the spectra with those of synthetic UDP. NMR data $\left({ }^{1} \mathrm{H}\right.$ and ${ }^{31} \mathrm{P}$ ) of the bioactive peak and of synthetic UDP, also shown in Figs. S1 \& S2, confirm this.

In the behavioral bioassays used to verify the identification procedures, synthetic UDP elicits the induction of the stereotyped cradling behavior typical for female-male pair formation (Trial 1: Mann-Whitney $U$-test, $U=290.0, \mathrm{n}_{1,2}=20, \mathrm{p}<0.001$, Trial 2: $\chi^{2}=16.94$, $\mathrm{df}=1, \mathrm{p}<0.001$, Trial 3: chi-square test, $\chi^{2}=12.12, \mathrm{df}=$ $1, \mathrm{p}<0.001 ; \mathrm{n}=20$ per trial; Fig. 5a), whilst none of the other synthetic nucleotides elicited the cradling behavior (data not shown, as all were negative). The minimum reaction threshold for synthetic UDP to induce the full cradling behavior was determined to be $0.10 \mathrm{ml}$ of a $10^{-5} \mathrm{M}$ solution, representing a total of $0.4 \mu \mathrm{g}$ UDP in our test aquarium. We also compared the bioactivity threshold of synthetic UDP with that of the original female urine sample (ca. $1000 \mathrm{BE}, \mathrm{n}=20$ females), and calculated the quantity of synthetic UDP potentially required in a urine sample to explain its bioactivity on males and compared this value with the level of UDP we detected in the female urine via HPLC (Table S1 in the Supplement). This was designed to examine whether all sex pheromone activity of a sample can be aligned to UDP or whether synergistic effects of other minor components in a potential bouquet could exist. The detectable UDP in female urine varied between individual females mainly because the volume of urine obtained varied $\left(0.15\right.$ to $1.9 \mathrm{ml}$ female $^{-1}$, average: $0.54 \mathrm{ml}$ ) whilst the urine UDP concentration was approximately $7.5 \times 10^{-5} \mathrm{M}$ (from $3.5 \times 10^{-5} \mathrm{M}$ to $1.5 \times$ $\left.10^{-4} \mathrm{M}\right)$. At this rate, just over $810 \mathrm{BE}$ of the $1000 \mathrm{BE}$ in the original female sample ( $\mathrm{n}=20$ females) could be attributed to UDP in urine.

Using a Y-shaped olfactometer (see Fig. 2 for design of this choice chamber) bioassay to assess responses over the seasons, we found that males preferred UDP to the feeding attractant glycine only during the reproductive months (June to September, Wilcoxon signed ranks, $n=20, p=0.005$; Fig. $5 b$ ). This seasonality of the pheromone response was also seen when examining cradling behavior. It was only during the reproductive
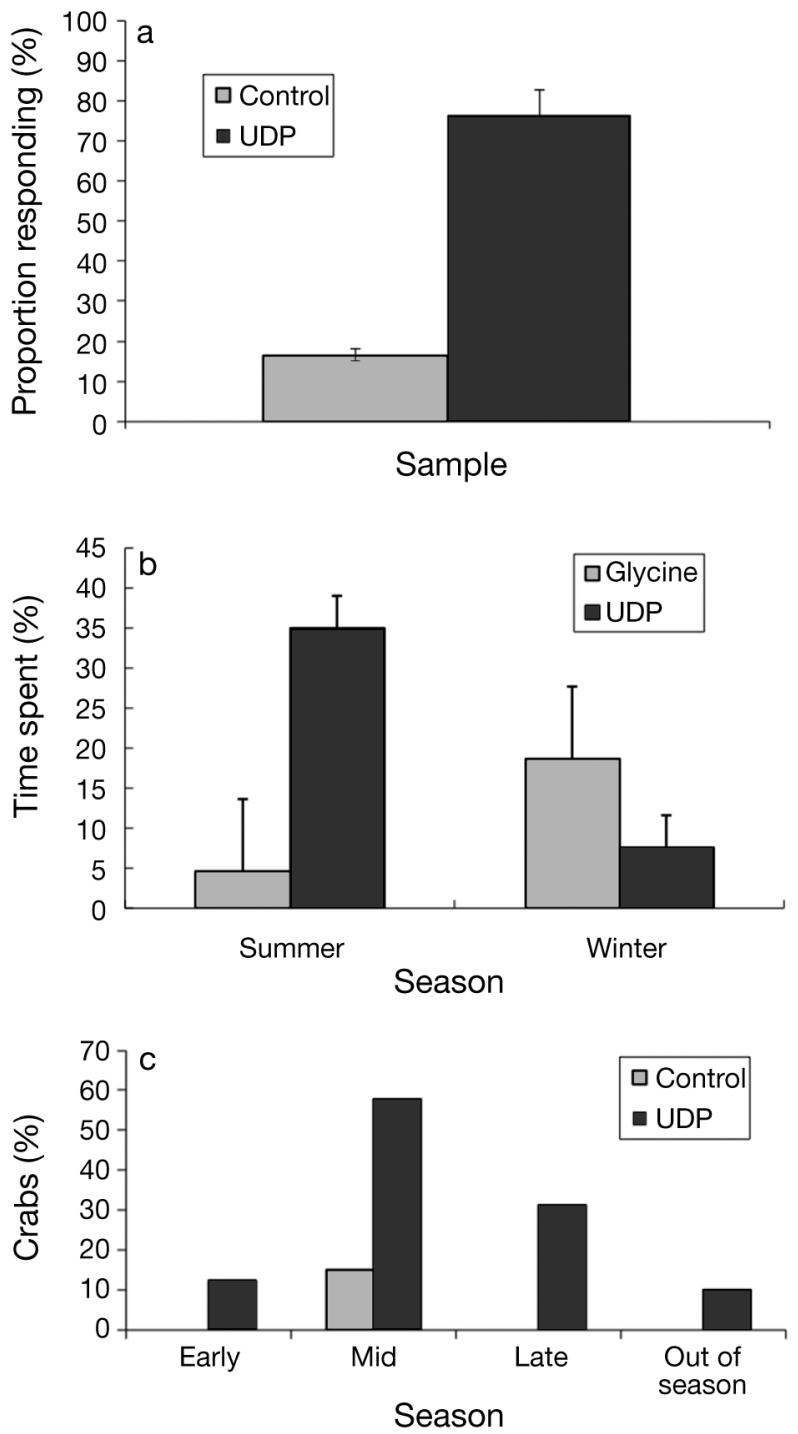

Fig. 5. Carcinus maenas. Sex pheromone responses in males and their seasonal variation. For behavioral assays with male green crabs using synthetic pheromone (UDP), crabs were exposed to $0.10 \mathrm{ml}$ of pheromone at a concentration of $5.0 \times$ $10^{-5} \mathrm{M}$, equaling approximately $2.0 \mu \mathrm{g}$. (a) Series of 3 bioassays with 20 males in each repeat, undertaken in a static tank using the mate-guarding stance as a positive result (data represent SEM). All experiments were undertaken during summer within the reproductive season with males collected as pre-copula pairs in the field. (b) Experiments undertaken in a choice chamber showing the percentage of time males spend in either the food stimulus (glycine) arm or the sex attraction (UDP) arm showing a significant preference for UDP (Wilcoxon signed ranks, $\mathrm{n}=20$, $\mathrm{p}=0.005$ ). Experiments were undertaken during the reproductive season (summer) as well as outside the reproductive season (winter). One $\mathrm{ml}$ of $10^{-4} \mathrm{M}$ UDP was added every $2 \mathrm{~min}$ using a peristaltic pump. (c) Seasonal differences in male response levels towards synthetic pheromone (UDP) with the only significant response to the synthetic pheromone in summer $\left(\chi^{2} / 3=13.48, \mathrm{p}<0.01\right)$. Pheromone concentration and bioassay procedure are as described in (a) 
season that males responded with cradling behavior when exposed to a sponge treated with UDP $\left(\chi^{2}=\right.$ 13.48, df $=3, \mathrm{p}<0.01$; Fig. 5c), whilst outside the breeding season, the pheromone showed little bioactivity (see also Hayden et al. 2007) when compared to feeding stimulants such as glycine.

Since our initial hypothesis was that the female sex pheromone production is ultimately linked to the female molt and potentially even the biochemical/ physiological changes during the molting process such as increased chitin biosynthesis, we also examined whether male urine during their epidemic molt in spring also contains UDP. Fig. 6 shows that this is the case, although UDP was found only in traces of less than $5 \%$ of the level detected in females (see Fig. 3) at levels $\left(3.1 \times 10^{-6} \mathrm{M}\right.$; range: $\left.0.1-5.5 \times 10^{-6} \mathrm{M}\right)$ well below the minimum threshold that would initiate a significant sexual response in sexually active males.

\section{DISCUSSION}

The characterization of UDP is the first conclusive chemical identification of a crustacean distance sex pheromone. Zhang et al. (2011) recently reported the identity of cuticle-bound contact sex pheromones in the simultaneously hermaphroditic shrimp Lysmata bogessi. These cuticluar hydrocarbons, of which (Z)-9octadeceneamide is the key compound within a pheromone bouquet, induced shrimp mating behavior after the sexual partners initially met through the attractiveness of a yet unknown distance pheromone. Contact pheromones may also play a role in other crustaceans but have not been postulated to exist in Carcinus maenas.

Early studies suggested a pheromone role of the molting hormone 20HE (Kittredge et al. 1971) and the peptide arthropodin (Dunham 1988). Both were dismissed for a range of species including green crabs (Eales 1973, Seifert 1982, Gleeson et al. 1984). The recent tentative identification of a novel ceramide as a pheromone in the hair crab Erimacrus isenbeckii (Asai et al. 2000) also proved inconclusive since behavioral assays did not support this conclusion (Asai et al. 2000); additionally, ceramides were not detectable in urine in biologically relevant concentrations. Biogenic amines, such as serotonin, octopamine, dopamine, and histamine, have been found to influence behavior in crustaceans (Beltz 1999). Specifically, Wood \& Derby (1996) showed that dopamine and the peptide proctolin produce several behaviors that are often seen within the courtship displays of the male blue crab Callinectes sapidus. When injected directly into the hemolymph, dopamine was found to initiate the mating posture, and proctolin initiated the rhythmic wav-

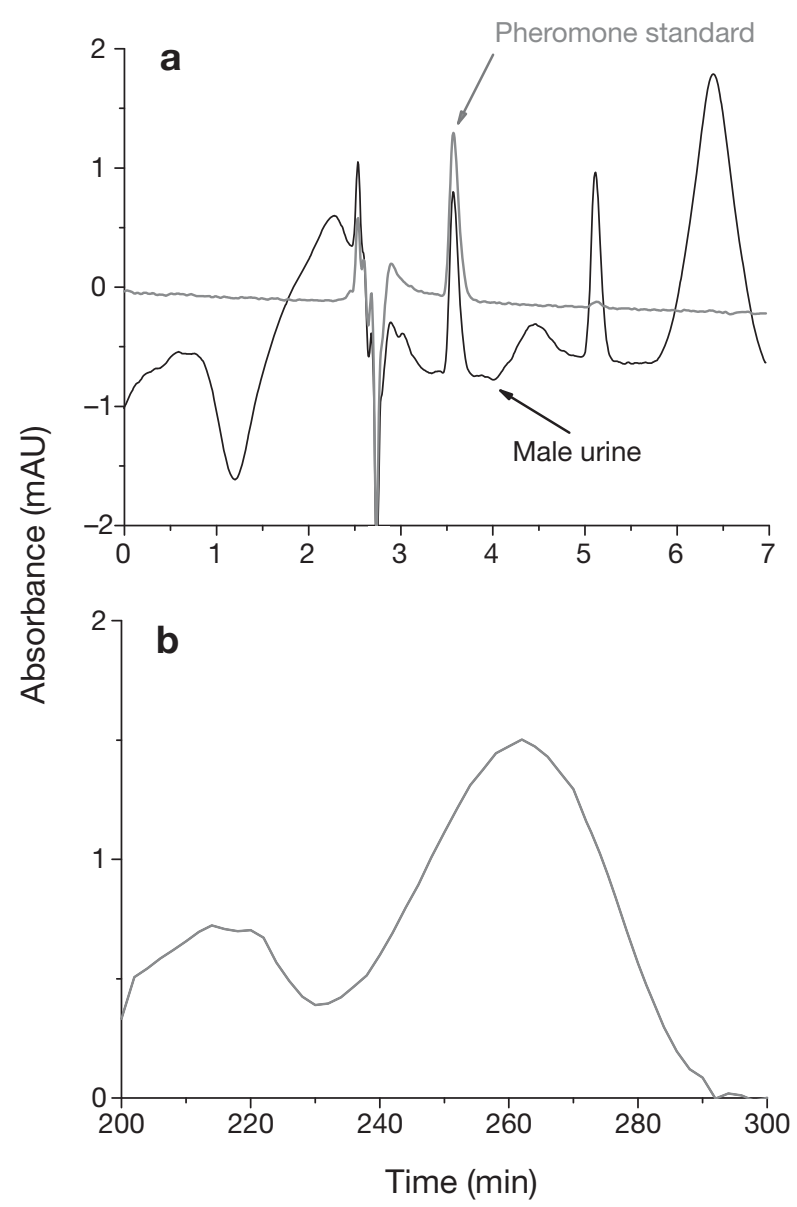

Fig. 6. Carcinus maenas. (a) Comparison of a male urine sample ( $2 \mathrm{~d}$ post-molt) and synthetic pheromone, UDP. The chromatogram here shows the HPLC analysis of male urine (black line) and is overlaid by a trace for UDP ( $5 \mu \mathrm{l}$ of $10^{-5} \mathrm{M}$, grey line). HPLC conditions used were: Phenomenex RP Fusion column $\left(4.6 \mathrm{~mm} \times 250 \mathrm{~mm}\right.$ ); mobile phase: $0.2 \mathrm{M} \mathrm{KH}_{2} \mathrm{PO}_{4}$ buffer, $\mathrm{pH} 5.5 ; 1 \mathrm{ml} \mathrm{min}^{-1}$. (b) UV spectrum of the peak at $3.3 \mathrm{~min}$ with a maximum absorbance at $260 \mathrm{~nm}$ as characteristic for UDP

ing of the male's pleopods, a characteristic mating behavior. Through radiolabeled serotonin Huber et al. (1997) determined that serotonin itself is not excreted in the urine, but its 3 major metabolic compounds are (serotonin-sulfate, $\beta$-alanine-, and $\beta$-alanine-sulfateconjugates). As such, the role of these compounds in the mating behavior remains unclear.

Although initially surprising that a simple nucleotide elicits the mating stance, the use of common compounds as pheromones is widespread in insects (Wyatt 2003). Aquatic examples include other nucleotides such as cAMP in slime molds (Konijn et al. 1967), glutathione-derived pheromones in polychaetes (Hardege et al. 2004), and steroids (Sorensen et al. 2005), amino acids (Yambe et al. 2006), and bile acids (Li et al. 2002) in fish. This elaborates on a fundamental question in 
animal signaling using chemicals, viz. the exclusivity of the compounds. Chemical signals must be detectable against a background of noise with the specificity of a signal being reaction-specific. As such, these cues effectively advertise the physiological or developmental stage of the sender (Chang 1995). Signal specificity is not necessarily based on structural exclusivity of the pheromone itself, but can be achieved through environmental timing or the use of specific bouquets of compounds (see Wyatt 2010 for definition and review). In fact, costs, mainly biochemical and physiological ones associated with producing a species and situation-specific chemical, can be prohibitive (Johansson \& Jones 2007), and separation in space and time through timing of events can be sufficient so that even a fixed action pattern reaction could be based on a non-exclusive compound such as seen in polychaetes (Hardege 1999). This raises the question of how species specificity is achieved in crustaceans where mating is linked to the female molt. Insect pheromone systems are often comprised of pheromone bouquets, i.e. mixtures of molecules in specific relative concentrations that, when taken as a whole, elicit the releaser reaction, allowing for species or population specificity (Christensen et al. 1989). Additionally, evolutionary changes of the mixtures may result in reproductive isolation as shown in turnip moths Agrostis segetum (Löfstedt 1993). Future work following the identification of UDP may include examining the potential existence of a pheromone bouquet potentially including contact sex pheromones as known from shrimps (Zhang et al. 2011). The bioactive threshold $\left(0.1 \mathrm{ml}\right.$ of $\left.10^{-5} \mathrm{M}\right)$ of the nucleotide cue is similar to other marine invertebrate sex pheromones (Sorensen et al. 2005). Although our data (Figs. 3 \& S1 to S6) make it likely that the unresolved shoulder peak detected represents both tautomeric forms of UDP, the bioassays with synthetic nucleotides show that we can only account for approximately $80 \%$ of the bioactivity of urine by UDP. There is a high degree of uncertainty included in such calculations since the exact volume and UDP content of each female's urine in a pooled sample used to purify the pheromone is unclear. Although in our study the female-conditioned seawater sample from 20 females had a total bioactivity similar to the sample obtained from urine (1000 BE) in earlier studies (Hardege et al. 2002; Table S1), we found almost twice as much pheromone activity in similar water samples. This may be indicative of pheromone release via sources other than urine as described by Bamber \& Naylor (1997), but could also be based on a pheromone bouquet with additional compounds or their synergistic effects. To clarify such questions, an improved, more sensitive purification strategy and better chromatographic resolution in HPLC detection need to be developed.
Unlike in mass spawning polychaetes (Hardege et al. 2004), not all males attempted to copulate when exposed to synthetic pheromone-treated objects (Fig. 5a). Although in Carcinus maenas sex pheromones induce males to approach, and often attempt mating, other cues including visual recognition of shape, hardness of the carapace, and female behavior play important roles in establishing pairs (Gleeson 1991). Receptiveness in males may also vary depending on social status and dominance hierarchies as described in lobsters (Breithaupt \& Atema 2000). Since male shore crabs are known to form 'hotspots' (lekking behavior; Ekerholm \& Hallberg 2005), it is to be expected that social interactions, including fighting, lead to the development of hierarchies, especially when males compete for females. In C. maenas, female pheromone exposure significantly affects the intensity of fighting behavior between males (Sneddon et al. 2003) with the loser of a fight showing a delayed and depressed reaction upon exposure to female sex pheromones (Fletcher \& Hardege 2009).

In crustacean feeding behavior, individuals can detect single cues from multi-component mixtures through selective receptor binding (Carr 1988, Derby et al. 2001). This allows for specific responses despite background noise and may represent a mechanism that applies for reproductive isolation between crab species. Interspecific activity of pheromones has been observed in male snow crabs Chionoecetes opilio that were guarding female crabs of Hyas araneus (SainteMarie et al. 1999), and Bublitz et al. (2008) recently found similar heterospecificity for the Carcinus pheromone. Timing of reproductive events and environmental control, as known in polychaete worms (Hardege et al. 2004), may be required to ensure premating reproductive isolation when common molecules are used as sex pheromones (Wyatt 2010). Derby \& Sorensen (2008) pointed out that in hormonal fish pheromones, the hormone systems are highly conserved and almost all pheromones identified are structurally related steroids and bile acids. There is little evidence for the evolution of novel hormonal compounds and their related receptors in fish (Wyatt 2010), and how widespread the use of nucleotides is in crustaceans remains to be examined. Christofferson (1978) found that a single unpaired male Portunus sanguinolentus in the presence of a coupled pair does not initiate courtship behavior. He attributed this to the lack of pheromone, due to the cessation of urine release, or the production of a masking factor. This highlights that even simple ecological factors such as digging the female into mud/sand underneath the male's abdomen to potentially reduce the release of female pheromone, or retrieval of pairs away from male hotspots into crevices higher up the shoreline, both often found in 
the field (Broekhuysen 1937, S. D. Bamber pers. obs.), may play a role in the spatial separation of pairs from competing males, at the same time reducing the need for signal specificity.

Pheromone cues of one species may affect other species differently, for example potentially functioning as a feeding stimulant when detected by a potential predator (Zimmer-Faust et al. 1984). Molted crabs are attractive prey for predatory fish and other crustaceans; nucleotides are known feeding stimulants in fish (Carr 1988). Interestingly, amongst the nucleotides tested as feeding stimulants, UDP is often the nucleotide with the lowest degree of feeding activity and was found as a feeding cue only in mackerel (Ikeda et al. 1991). In many crustaceans, responses to sex pheromone differ significantly from feeding behavior and can rarely be confused (see Hayden et al. 2007). Nevertheless, the potential abundance of other organisms detecting nucleotides released into the environment makes it likely that green crabs have developed mechanisms to reduce predation risks, such as the guarding behavior, reduced rates of urine release at the time of ecdysis (Eales 1973), or the use of a bouquet, thus reducing the potential cost of pheromone release. Nucleotide pheromones could be regarded as potentially costly by alerting a predator and biochemically costly because nucleotides are energy carriers. The appearance of these costly compounds in excretions into the environment must outweigh their production value. Reflecting upon biological amines, Huber et al. (1997) speculated that this is because they serve as conspecific communicators. We propose that the Carcinus maenas pheromone represents an ideal system to test the costs of aquatic chemical signals. Species specificity may not be essential if other ecological avoidance mechanisms (timing, spatial isolation, receptor activation, seasonality, behavior) are in place, thus allowing for simple, reaction-specific molecules such as nucleotides, peptides, or amino acids to function as pheromones (Hardege et al. 2004, Yambe et al. 2006). We hypothesize this concept to be widespread amongst marine organisms.

Female sex pheromone production is linked to the molt cycle (Adelung 1971, Kittredge et al. 1971, Gleeson et al. 1984), and Bamber \& Naylor (1997) suggested that pheromone release rates increase after ecdysis when the new carapace hardens. Gonad development leads to an increase of nucleosides as well as pyrophosphate and a decline in glucose (Fittschen 2001). Chitin ( $\beta-1,4$ linked modified glucose polysaccharide) biosynthesis requires nucleotides as phosphate donors for the enzymatic reactions of UDPacetylglucosamine into chitin (Mansecal 1999), of which UDP is a metabolic byproduct (Peters et al. 1999, Merzendorfer \& Zimoch 2003). That UDP production is linked with the molt is also confirmed by our analysis of urine collected from males around the time of their molt (Fig. 6). Although only found at a very low concentration of less than $5 \%$ of the UDP levels found in post-molt female urine (see Figs. 3 \& 6 for comparison), the nucleotide is present in urine of molting males, whereas it is absent in inter-molt male or inter-molt female urine and in juvenile crabs $<3 \mathrm{~cm}$ in size. However, it is unclear whether males actually release any UDP with their urine. Conditioned seawater samples from males showed no HPLC peaks corresponding to the retention time of this nucleotide (Hardege et al. 2002) mainly because the detection level of UDP in seawater containing samples is higher than the actual amounts released by males. Urine UDP levels in male crabs are also significantly below the minimum threshold required to induce sexual behavior in males (see Fig. 6, Table S1). In behavioral assays with sexually active males, the male molt urine samples never induced any grade 4 or 5 mating stance. This is in conjunction with Bamber \& Naylor (1996), who stated that males will very rarely respond (if ever) to the urine sampled from and pre- and post-molt males. If any response did occur, males would only raise up on extended pereopods 2-4 and show limited searching behavior, which represents a level of response not considered significantly different from feeding responses, and as such are not deemed bioactive (see Table S1). For males, spring is the time of epidemic molt; the majority of males molt in April to May, thereby reducing the risk of same-sex mating pairs (Broekhuysen 1937). Male-male pairs very occasionally appear in the field in late June, early in the spawning season, and usually consist of a large sexually active male grasping a small sexually immature individual (male or female) during their juvenile molt (Broekhuysen 1937, S. D. Bamber \& J. D. Hardege pers. obs.). It is therefore plausible, but not proven, that UDP release is a direct result of chitin biosynthesis, advertising the physiological state of the sender (Chang 1995, Sorensen \& Stacey 1999), here a freshly molted female crab. The concept of chemical spying, first described in goldfish (Sorensen \& Stacey 1999), implies that pheromones characterize an organism's physiology, enabling the receiver to make an informed choice about the sender's quality.

In Carcinus maenas, males may use the excretion of pheromones and molt-related compounds such as crustecdysone to detect the molting stage of females (Adelung 1971), potentially allowing for male mate choice. Only once the female carapace hardens does male investment in guarding effort become minimal; this is because of reduced predation and male competitor displacement risks (Van der Meeren 1994). After insemination, a sperm plug that solidifies is 
employed, but this does not entirely prevent other males from mating with the female (Gosselin et al. 2003). It may therefore be advantageous for dominant males to mate late in the female molt cycle since males are able to mate numerous times in succession (Van der Meeren 1994). It has been observed that the postcopulation embrace is lengthened by the presence of competitors (Van der Meeren 1994), and there is evidence for size assortative mating (Gosselin et al. 2003). Multiple paternity is known in crustaceans (SainteMarie et al. 1999), but is unconfirmed for C. maenas. By signaling their reproductive status (Li et al. 2002), females may utilize UDP to advertise their short window of mating opportunity to attract and select partners or to increase paternal diversity in situations when the density of large males is low and predator pressure is high (Gosselin et al. 2003).

Since sexual signals can derive from feeding stimulants (Stoka 1999), and nucleotides function as such, it will be interesting to establish how complex signaling systems involving sexual and feeding behavior have evolved in crustaceans. Structure-activity relationships found for amino acid and nucleotide feeding responses are very similar to those for their uses in internal signal reception (Carr et al. 1988). This points towards an evolutionary link between the chemoreceptors that monitor the external and internal (but extracellular) environment. Adapted from the Haldane hypothesis, this potentially allows for the evolution of external signals from such internal messenger molecules (Carr et al. 1988). The identification of a nucleotide as a crustacean sex pheromone will potentially stimulate research into signal identification and biological function of pheromones in crustaceans. This could include studies on mate choice, honesty of signals, and specificity of marine chemical cues that all benefit from structural information on the chemical nature of signaling cues (Johansson \& Jones 2007).

Acknowledgements. We thank M. Huffee, M. Smith, L. Watkins, M. Beckmann, M. Davies, H. Marshall, C. Tayler, M. Dean, L. Davidson, and I. Hardege for help during field work, crab sampling, data analysis, and initial discussion, and T. Breithaupt for comments on the manuscript. We thankfully acknowledge JW-Aquaculture and the Natural Environment Research Council (NERC) for financial support (NER/B/S/ 2003/00224 and NER/S/C/2004/12985).

\section{LITERATURE CITED}

Adelung D (1971) Untersuchungen zur Häutungsphysiologie der dekapoden Krebse am Beispiel der Strandkrabbe, Carcinus maenas. Helgol Wiss Meeresunters 22:66-119

> Asai N, Fusetani N, Matsunaga S, Sasaki J (2000) Sex pheromones of the hair crab Erimacrus isenbeckii. Part 1: isolation and structures of novel ceramides. Tetrahedron 56:9895-9899
Bamber SD, Naylor E (1996) Chemical communication and behavioural interaction between sexually mature male and female shore crabs (Carcinus maenas). J Mar Biol Assoc UK 76:691-699

Bamber SD, Naylor E (1997) Sites of release of putative sex pheromone and sexual behaviour in female Carcinus maenas (Crustacea: Decapoda). Estuar Coast Shelf Sci 44: 195-202

> Beltz BS (1999) The distribution and functional anatomy of amine-containing neurons in decapod crustaceans. Microsc Res Tech 44:105-120

Berrill M, Arsenault M (1982) Mating behaviour of the green shore crab Carcinus maenas. Bull Mar Sci 32:632-638

Breithaupt T, Atema J (2000) The timing of chemical signaling with urine in dominance fights of male lobsters (Homarus americanus). Behav Ecol Sociobiol 49:67-78

Broekhuysen GJ (1937) On development, growth, and distribution of Carcinides maenas. Arch Neerl Zool 2:257-400

Bublitz R, Sainte-Marie B, Newcomb-Hodgetts C, Fletcher N, Smith M, Hardege JD (2008) Interspecific activity of sex pheromone of the European shore crab (Carcinus maenas). Behaviour 145:1465-1478

Carr WES (1988) The molecular nature of chemical stimuli in the aquatic environment. In: Atema J, Fay RR, Popper AN, Tavolga WN (eds) Sensory biology of aquatic animals. Springer-Verlag, New York, NY, p 3-27

Carr WES, Gleeson RA, Trapido-Rosenthal HG (1988) Olfactory responses of crustaceans with similarities to internal receptors for neuroactive substances. In: Fautin DG (ed) Biomedical importance of marine organisms. California Academy of Sciences, San Francisco, CA, p 115-129

Chang ES (1995) Physiological and biochemical changes during the molt cycle in decapod crustaceans: an overview. J Exp Mar Biol Ecol 193:1-14

Christensen TA, Mustaparta H, Hildebrand JG (1989) Discrimination of sex pheromone blends in the olfactory system of the moth. Chem Senses 14:463-477

> Christofferson JP (1978) Evidence for the controlled release of a crustacean sex pheromone. J Chem Ecol 4:633-639

Derby CD, Sorensen PW (2008) Neural processing, perception, and behavioural responses to natural chemical stimuli by fish and crustaceans. J Chem Ecol 34:898-914

Derby CD, Steullet P, Horner AJ (2001) The sensory basis to feeding behavior in the Caribbean spiny lobster Panulirus argus. Mar Freshw Res 52:1339-1350

- Dulka JD, Stacey NE, Sorensen PW, Van Der Kraak GJ (1987) A steroid sex pheromone synchronizes male-female spawning readiness in goldfish. Nature 325:251-253

Dunham PJ (1978) Sex pheromones in Crustacea. Biol Rev Camb Philos Soc 53:555-583

Dunham PJ (1988) Pheromones and behaviour in Crustacea. In: Laufer H, Downer R (eds) Endocrinology of selected invertebrate types. Alan R. Liss, New York, NY, p 375-392

Eales AJ (1973) Sex pheromone in the shore crab Carcinus maenas, and the site of its release from females. Mar Behav Physiol 2:345-355

> Ekerholm M, Hallberg E (2005) Primer and short-range releaser pheromone properties of premolt female urine from the shore crab Carcinus maenas. J Chem Ecol 31: 1845-1864

Fittschen UEA (2001) Identifizierung von Naturstoffprofilen aus der Nordseekrabbe Crangon crangon. PhD thesis, University of Hamburg

- Fletcher N, Hardege JD (2009) The cost of conflict: Agonistic encounters influence responses to chemical signals in the shore crab, Carcinus maenas. Anim Behav 77:357-361

Gleeson RA (1991) Intrinsic factors mediating pheromone 
communication in the blue crab Callinectes sapidus. In: Bauer RT, Martin JW (eds) Crustacean sexual biology. Columbia Press, New York, NY, p 17-32

Gleeson RA, Adams MA, Smith AB (1984) Characterization of a sex pheromone in the blue crab, Callinectes sapidus: crustecdysone studies. J Chem Ecol 10:913-921

Gosselin T, Sainte-Marie B, Bernatchez L (2003) Patterns of sexual cohabitation and female ejaculate storage in the American lobster (Homarus americanus). Behav Ecol Sociobiol 55:151-160

Grosholz ED, Ruiz GM (1995) Spread and potential impact of the recently introduced European green crab, Carcinus maenas, in central California. Mar Biol 122:239-247

> Hardege JD (1999) Nereid polychaetes as model organism for marine chemical ecology: a review. Hydrobiologia 402: 145-161

Hardege JD, Jennings A, Hayden D, Müller CT, Pascoe D, Bentley MG, Clare AS (2002) Novel behaviour assay and partial purification of a female-derived sex pheromone in Carcinus maenas. Mar Ecol Prog Ser 244:179-189

- Hardege JD, Bartels-Hardege H, Müller CT, Beckmann M (2004) Peptide pheromones in female Nereis succinea. Peptides 25:1517-1522

Hayden D, Jennings A, Müller C, Pascoe D and others (2007) Sex-specific mediation of foraging in the shore crab, Carcinus maenas. Horm Behav 52:162-168

Huber R, Smith K, Delago A, Isaksson K, Kravitz EA (1997) Serotonin and aggressive motivation in crustaceans: altering the decision to retreat. Proc Natl Acad Sci USA 94: 5939-5942

Ikeda I, Hosokawa H, Shimeno S, Takeda M (1991) Feeding stimulant activity of nucleotides, tryptophan and their related compounds for jack mackerel. Nippon Suisan Gakkaishi 57:1539-1542

Johansson BG, Jones TM (2007) The role of chemical communication in mate choice. Biol Rev Camb Philos Soc 82: 265-289

- Jormalainen V (1998) Precopulatory mate guarding in crustaceans: male competitive strategy and intersexual conflict. Q Rev Biol 73:275-304

Kittredge JS, Terry M, Takahashi FT (1971) Sex pheromone activity of the molting hormone crustecdysone on male crabs (Pachygrapsus crassipes, Cancer anternnarius and Cancer anthonyi). Fish Bull 69:337-343

Konijn TM, Van de Meene JGC, Bonner JT, Barkley DS (1967) The acrasin activity of adenosine- $3^{\prime}, 5^{\prime}$-cyclic phosphate. Proc Natl Acad Sci USA 58:1152-1154

Li W, Scott AP, Siefkes J, Yan H, Liu Q, Yun SS, Gage DA (2002) Bile acid secreted by male sea lamprey that acts as a sex pheromone. Science 296:138-141

Löfstedt C (1993) Moth pheromone genetics and evolution. Philos Trans R Soc Lond B Biol Sci 340:167-177

Mansecal R (1999) Chitin. In: Mark JE (ed) Polymer data handbook. Oxford University Press, New York, NY, p 67-69

Merzendorfer H, Zimoch L (2003) Chitin metabolism in insects: structure, function and regulation of chitin syn- thases and chitinases. J Exp Biol 206:4393-4412

Peters G, Saborowski R, Buchholz F, Mentlein R (1999) Two distinct forms of the chitin-degrading enzyme N-acetyl- $\beta$ D-glucosaminidase in the Antarctic krill: specialists in digestion and molt. Mar Biol 134:697-703

> Ryan EP (1966) Pheromone: evidence in a decapod crustacean. Science 151:340-341

Sainte-Marie B, Urbani N, Sévigny JM, Hazel F, Kühnlein U (1999) Multiple choice criteria and the dynamics of assortative mating during the first breeding season of female snow crab Chionoecetes opilio (Brachyura, Majidae). Mar Ecol Prog Ser 181:141-153

Seifert P (1982) Studies on the sex pheromone of the shore crab, Carcinus maenas, with special regard to ecdysone excretion. Ophelia 21:147-158

Simpkin BY (1978) Theoretical study of the tautomerism of nucleotide bases in the gas phase and in aqueous media. Khimiya Geterotsiklicheskikh Soedinenii (Chem Heterocycl Compd) 1:94-99 (in Russian, with English abstract)

> Sneddon LU, Huntingford FA, Taylor AC, Clare AS (2003) Female sex pheromone-mediated effects on behaviour and consequences of male competition in the shore crab (Carcinus maenas). J Chem Ecol 29:55-70

Sorensen PW, Stacey NE (1999) Advances in chemical signals in vertebrates. Klüwer Publishers, New York, NY

Sorensen PW, Fine JM, Dvornikovs V, Jeffrey CS and others (2005) Mixture of new sulfated steroids functions as a migratory pheromone in the sea lamprey. Nat Chem Biol 1:324-328

- Stoka AM (1999) Phylogeny and evolution of chemical communications: an endocrine approach. J Mol Endocrinol 22:207-225

Van der Meeren GI (1994) Sex- and size-dependent mating tactics in a natural population of shore crabs Carcinus maenas. J Anim Ecol 63:307-314

> Wood DE, Derby CD (1996) Distribution of dopamine-like immunoreactivity suggests a role for dopamine in the courtship display behavior of the blue crab, Callinectes sapidus. Cell Tissue Res 285:321-330

Wyatt TD (2003) Pheromones and animal behaviour. Cambridge University Press, Cambridge

Wyatt TD (2010) Pheromones and signature mixtures: defining species-wide signals and variable cues for identity in both invertebrates and vertebrates. J Comp Physiol A Neuroethol Sens Neural Behav Physiol 196:685-700

Yambe H, Kitamura S, Kamio M, Yamada M, Matsunaga S, Fusetani M, Yamazaki F (2006) L-Kynurenine, an amino acid identified as a sex pheromone in the urine of ovulated female masu salmon. Proc Natl Acad Sci USA 103: 15370-15374

Zhang D, Terschak J, Harley M, Lin J, Hardege JD (2011) Contact pheromones in a simultaneous hermaphroditic shrimp, Lysmata boggessi. PLoS ONE 6:e17720

Zimmer-Faust RK, Tyre JE, Michel WC, Case JF (1984) Chemical mediation of appetitive feeding in a marine decapod crustacean: the importance of suppression and synergism. Biol Bull (Woods Hole) 167:339-353
Editorial responsibility: Pei-Yuan Qian, Kowloon, Hong Kong SAR
Submitted: February 13, 2010; Accepted: May 25, 2011

Proofs received from author(s): August 16, 2011 